\title{
How can integrated valuation of ecosystem services help understanding and steering agroecological transitions?
}

\author{
Nicolas Dendoncker $^{1}, \underline{\text { Fannv Boeraeve }}^{2}$, Emilie Crouzat $^{3}$, Marc Dufrêne $^{4}$, Ariane König $^{5}$ and Cecile Barnaud $^{6}$
}

\begin{abstract}
Agroecology has been proposed as a promising concept to foster the resilience and sustainability of agroecosystems and rural territories. Agroecological practices are based on optimizing ecosystem services (ES) at the landscape, farm, and parcel scales. Recent progress in research on designing agroecological transitions highlights the necessity for coconstructed processes that draw on various sources of knowledge based on shared concepts. But despite the sense of urgency linked to agroecological transitions, feedbacks from real-world implementation remain patchy. The ability of integrated and participatory ES assessments to support this transition remains largely underexplored, although their potential to enhance learning processes and to build a shared territorial perspective is widely recognized. The overarching question that will be asked in this paper is thus: what is the potential of the ES framework to support the understanding and steering of agroecological transitions? We argue that conducting collaborative and integrated assessments of ES bundles can (i) increase our understanding of the ecological and social drivers that support a transition toward agroecological systems, and (ii) help design agroecological systems based on ES delivery and effectively accompany transition management based on shared knowledge, codesigned future objectives, and actual on-the-ground implementation. In this paper, we discuss this question and propose a four-step integrated ES assessment framework specifically targeted at understanding and steering agricultural transitions that is generic enough to be applied in different contexts.
\end{abstract}

Key Words: agrocological transition; integrated ecosystem services valuation; transdisciplinarity

\section{INTRODUCTION}

Conventional intensive moto-mechanized agriculture is not sustainable for a broad range of reasons, including the rarefaction of inputs such as fossil fuel and phosphate-based fertilizers, global competition, and climate change, but also the loss of biodiversity and ecosystem services (ES). Ecosystem services make explicit "the benefits people obtain from ecosystems" (Millenium Ecosystem Assessment (MEA) 2005). They are defined as "the direct and indirect contributions of nature to human wellbeing" (The Economics of Ecosystems and Biodiversity (TEEB) 2010) and stress human dependency on natural processes (Díaz et al. 2015). Thus, the concept of ES directs attention to interactions and interdependencies of nature, society, and economy. The sustainability of agriculture depends on a broad suite of ES, such as renewable fertile topsoil and insect-borne pollination of diverse crops (Zhang et al. 2007). However, as shown by the MEA (2005) and, more recently, by Costanza et al. (2014), ES are declining in many parts of the world. For example, carbon content levels in agricultural soils are critical in many areas, topsoil is lost at worrying rates, and numbers of farmland birds are rapidly decreasing (Donald et al. 2006). Moreover, as discussed by Davila and Dyball (2018), a myriad of conflicting priorities held by parties with different power and economic agency has led to significant inequities (e.g., in access to food) and created a global "wicked problem." To engage with this, there is a need to better understand the interactions between the social, technological, economic, and environmental dimensions of agricultural systems as well as the interdependencies and feedbacks between these dimensions, developing a system's perspective.

Many studies show that it is possible to feed a growing population differently, by taking into account the diverse dimensions of agricultural systems for sustainability (e.g., de Schutter 2014, TEEB 2015). Although some authors argue that there is still a yield gap between industrial and organic farming for example (Seufert et al. 2012), others find that integrating ecological principles into agricultural practices can increase both food production and other ES (Ponisio et al. 2014, Garbach et al. 2017). Importantly, organic farming does not necessarily mean sustainable farming (Kremen et al. 2012) as, for example, it does not include a social dimension and may sometimes lead to increased greenhouse gas emissions by replacing herbicides with mechanical weeding. Among alternatives to conventional agriculture, agroecology arguably has the broadest meaning, as it refers to a science, a set of practices, but also a social movement (Wezel et al. 2009). Agroecology approaches farm systems from ecological and socioeconomic stances, its main objective originally being the development of sustainable and healthy production systems (Altieri 1989). Agroecology covers diverse practices, ranging from improving the efficiency of input use and minimizing farming environmental impacts to increasing the contribution of functional biodiversity and ES to agricultural processes and products (Duru and Thérond 2015).

Transforming conventional farm systems to agroecological ones requires an agroecological transition (Gliessman 2009), which corresponds to the conversion of intensive systems to more complex and sustainable agroecosystems based on renewed practices (e.g., diversified cropping systems, mosaic landscapes, low anthropogenic inputs...) and on a reconnection between the farming system and its ecological and social environment. Resilience is one of the main stated goals of the transition to sustainable agroecological systems. Current conventional motomechanized agricultural systems have been described as not

${ }^{1}$ Department of Geography, Institute Transitions, University of Namur, ${ }^{2}$ Gembloux Agro-Bio Tech, Unity Biodiversity and Landscapes, University of Liege, ${ }^{3}$ Laboratoire d'Ecologie Alpine, CNRS, Université Grenoble Alpes, ${ }^{4}$ Gembloux Agro-Bio Tech, TERRA research unit, Biodiversity and Landscape team, University of Liege, ${ }^{5}$ Research Unit on Education, Cognition, Culture and Society, University of Luxembourg, ${ }^{6}$ DYNAFOR, Université de Toulouse, INPT, INRA, Toulouse, France 
resilient because they work as a vertical chain of interdependent links, meaning that if one of the links breaks, the whole food system fails (Servigne and Stevens 2015). For example, should the oil supply break down, moto-mechanized farming systems would likely collapse. Conversely, the dependency of agroecological systems upon ecological processes and functions works as a network, making the system less sensitive to breaking links.

Sustainable agroecological systems also strive for autonomy. Autonomy aims at closing cycles, producing one's own organic farmyard manure, transforming products, and being able to choose whom to sell these products to. A resilient system is also a diverse system at multiple scales. For instance, in an agroforestry farm, cereals can be grown under trees and be protected by hedges. In a diverse system, each of these elements plays a different and/ or complementary role in the agricultural landscape to contribute to a large diversity of ecological functions. As developed below, these functions provide ES to the farming systems themselves and to society. Agroecology thus addresses environmental, economic, and social concerns, which requires new conceptual and yet operational tools to direct attention at the interface and interdependence of changes in society, well-being, economy, and the environment.

The "ES concept" offers such tools and a conceptual framework combining these dimensions. It is also increasingly advocated to be included in land-use planning and decision-support tools (Cowling et al. 2008, Collins et al. 2010). A large body of literature investigates how this concept can be used in an agricultural context (Zhang et al. 2007, Power 2010, Duru and Thérond 2015, Landis 2017, etc.). Several studies have used the concept to assess impacts of different agricultural practices (e.g., Sandhu et al. 2010, Barral et al. 2015, Rapidel et al. 2015). Although these provide information on which practice optimizes best ES delivery, they do not address how to implement these practices on the ground. In other words, there is a gap between the knowledge on agricultural practices and ES delivery and the knowledge on agricultural transition. The few ES valuations in the context of agriculture aiming at decision support seem to be mainly limited to theoretical reflections (e.g., Holt et al. 2016) and/or to agrienvironmental schemes (Tscharntke et al. 2005, Prager et al. 2012, Merckx and Pereira 2015), failing to provide guidance for effective implementation.

To answer this gap, the main objective of this paper is to discuss the potential of the ES concept to act as an operational tool to understand and steer the needed agricultural transition. First, we examine how ES are related to agroecosystems in the light of the existing literature. Second, we propose a four-step integrated valuation framework to use ES as an agroecological transition tool, helping to understand and steer agroecological transitions. This framework is based on previous research and will be tested in further ongoing research. Finally, we draw and discuss some limitations of the ES concept with regard to the agroecological shift that should be implemented for increased sustainability.

\section{INTEGRATED ECOSYSTEM SERVICES VALUATION TO FOSTER AGRICULTURAL TRANSITIONS}

\section{Ecosystem services in agroecosystems}

Well-functioning and sustainable agroecosystems rely on a broad range of ES, such environments in turn provide another diverse set of ES to their beneficiaries. For example, agroecosystems will benefit from a living soil rich in organic matter, which will help increase production, providing income to farmers and food to society (Adhikari and Hartemink 2016). The presence of crop auxiliaries can also increase agricultural productivity (Östman et al. 2003), while decreasing the financial and health costs of pesticides (Weisenburger 1993).

However, as Peeters et al. (2013) mention, since the middle of the 19th century, a large part of the ES provided by ecosystems before the Industrial Revolution has been replaced by techniques relying on a massive use of fossil fuel. For instance, the artificial synthesis of nitrogen, which requires vast amount of energy, has replaced symbiotic nitrogen fixation by legumes, crop protection by pesticides has replaced the biological control of pest and disease regulation by complex assemblages of living communities, and motorization has replaced manpower and draft animals.

Although the use of these artificial inputs and techniques has increased production, this replacement of ES, accompanied by a landscape simplification, induced negative impacts on the environment and on society (Costa et al. 2014, Tilman and Clark 2014). They provoked pollution and biodiversity losses that, in turn, decreased the supply of ES essential to farming itself and to society (Zhang et al. 2007, Dendoncker and Crouzat 2018, Landis 2017).

\section{Limits of pure economic assessments of ecosystem services for agroecological transitions}

In a free market economy, farmers will perceive the benefits of high yields generated by chemical fertilizers, but may not or only partially pay the so-called negative externalities, i.e., the environmental costs generated for instance by the loss of nitrogen in water tables or in the atmosphere. Conversely, externalities from agricultural activities can also be positive. For example, wellmaintained grasslands store vast amounts of carbon, thus contributing to mitigating climate change (Gelfand and Robertson 2015), which benefits the broader society. As this ES is generally neither recognized nor paid (it escapes the market), it is produced in a suboptimal quantity by farmers (Robertson and Prior-Murray 2008). The free market economic logic leads "rational" farmers to maximize provisioning services (for which there is a market) at the expense of other categories of ES (for which there is no market) (Bohlen et al. 2009). At the local level, numerous attempts to internalize environmental externalities are already occurring across the planet under Payment for Environmental Services (PES) schemes, which can be considered as the main attempt to operationalize the ES concept. Agrienvironmental schemes (AEM) are one example of PES in the European Union (Engel et al. 2008).

Although such instruments can play a role in improving environmental governance, they face a series of limitations. Muradian et al. (2013) argue that the design of payment schemes is susceptible to politicization, meaning that PES might get influenced by powerful pressure groups shaping their effectiveness and distributional outcomes. Payment for Environmental Services schemes can also sometimes act as incentive for perverse strategic behavior when eligibility criteria for getting the payments are not properly designed (Banerjee et al. 2013). In addition, some authors are concerned by the shift PES induce from a polluterpays principle to a beneficiary-pays principle (Pirard et al. 2010). 
Most importantly, Muradian et al. (2013) argue that it is necessary now to shift the emphasis to tackling the ultimate causes of environmental degradation, deeply rooted in structural power inequalities. Thus, internalizing externalities and/or creating a market for nonprovisioning ES, a process referred to as the commodification of nature, will likely not be sufficient to ensure sustainable farming and may even reinforce current unsustainability issues such as access to resources and power asymmetries (Kallis et al. 2013, Boeraeve et al. 2015).

\section{Integrated ecosystem services valuation as a transition tool}

As Jacobs et al. (2013) state, the research field and concept of ES are rooted in strong sustainability thinking. The three pillars of sustainability and their subsequent values are indeed required when valuing ES: ecological values, social values, and economic values. These values are embedded into each other: economy and society are dependent upon the environment and bound to operate within safe ecological boundaries (Boeraeve et al. 2015). Conclusively, the final goal of ES valuation should be to achieve a more sustainable resource use, contributing to the well-being of every individual, now and in the future, by providing an equitable, adequate, and reliable flow of essential ES to meet the needs of a burgeoning world population (Jacobs et al. 2013).

Ecosystems are shaped by actors of agricultural landscapes and deliver a broad range of benefits. Thus, they involve many different actors: from coproducers and managers of ES (e.g., farmers, foresters) to ES beneficiaries (e.g., local inhabitants, tourists). In order to encourage sustainable landscape management, an integrated valuation framework including a broad set of values and stakeholders seems particularly relevant. As argued by Funtowicz and Ravetz (1993), in situations where scientific uncertainties or social stakes are high as is the case with ES valuations, scientists should adopt a postnormal posture in which they engage in dialog and knowledge coconstruction with decision makers and stakeholders (see also Barnaud and Antona 2014).

An integrated valuation framework is needed to reveal the diversity of values that can be attributed to ES. Assessing and valuing ES imply accounting for cognitive (what is) and normative (what should be) complexities and uncertainties. Such a framework is integrated if it offers a way to articulate different value domains (e.g., biophysical, social, economic) and inclusive if it does so by involving the broad set of stakeholders concerned with the valuation case (Dendoncker et al. 2013). This allows the assessment to be more sensitive and responsive to the needs and values harbored by stakeholders (Fontaine et al. 2014). The need to address the social component within such analysis is strong in agricultural contexts, as societal goals of today's agriculture go beyond food production. Indeed, consumers demand quality, are increasingly guided by their ethics (Boogaard et al. 2010), and value traditional heterogeneous and complex landscapes as aesthetic and educational resources (Lindemann-Matthies et al. 2010). In return, in addition to earning a fair living, farmers call for recognition of the role they play in society (Pascual and Perrings 2007).

Over recent years, many place-based case studies have tried to value ES. Many invoke improved decision making as a vindication for their research. However, it is unclear whether these have actually led to improved landscape management (Laurans et al.
2013, Laurans and Mermet 2014). Although acknowledging the limitations they meet, integrated and inclusive ES valuation initiatives may lead to increasingly sustainable agricultural landscapes: they could improve environmental quality, reduce inequalities, and account for and maintain value plurality (Jacobs et al. 2016).

How can an integrated ecosystem services valuation framework help in understanding and steering agroecological transitions? Understanding how agricultural practices influence ES flows, which in turn impact agricultural productivity and society, is of great importance (Dale and Polasky 2007, Duru and Thérond 2015). This would help informing management decisions toward practices less harmful to the environment and more in line with consumer and local inhabitant expectations. To nourish this understanding, there is a need to thoroughly understand ecological functions and processes, their interlinkages, and their relationship to change in practices, but also how stakeholders perceive and value ES and react upon changes in ES flows (Landis 2017).

A review by Kremen and Miles (2012) comparing the provision of 12 ES in conventional farming systems and in agroecological farming systems concludes that "integrated whole-system studies of the influence of different farming practices on multiple ES are critically needed;" a conclusion confirmed by the few existing farm-scale ES assessments (Porter et al. 2009, Sandhu et al. 2010). This involves analyzing whether ES stand in conflicting (tradeoffs) or reinforcing (synergies) relation to each other (GomezBaggethun et al. 2014). Furthermore, study of pairwise associations between ES should be extended to consider the consistent associations among multiple ES. These associations among multiple ES, also known as ES bundles (Raudsepp-Hearne et al. 2010), synthesize the typical set of ES associated with given subsystems. Bundles are composed by the types and magnitude of the ES supplied or demanded. They acknowledge the complexity of the social-ecological system by highlighting that all ES cannot be jointly maximized everywhere and under all management conditions and that social expectations regarding the "ideal" bundle of ES can vary. This information is necessary to provide a holistic picture of the social-ecological components of agricultural systems. As others, we argue that ES flows should be measured at several spatial scales (e.g., plot, farm, landscape, region) (Hein et al. 2006, Dale and Polasky 2007, Kremen et al. 2012) because different processes take place at different scales and because different scales will interest different stakeholders. Localscale assessments may lead to information more useful to farmers in terms of practical management, whereas broader extents will be more relevant to decision makers for land-use planning and rural development plans.

The agroecological transition is characterized by complex interdependencies between ecological and social components as well as by multilateral and power-driven interplays of stakeholders, which challenges its comprehensive understanding. As both pathways of change and outcomes remain unsure (Caron et al. 2014), steering the agroecological transition relies on a collaborative learning process involving all actors concerned by the agricultural matrix and its evolutions. Throughout this learning process, the capacity of individuals and communities to propose joint actions is progressively strengthened to face the 
Fig. 1. A four-step, iterative, methodological framework to steer agroecological transitions based on integrated ES assessment.
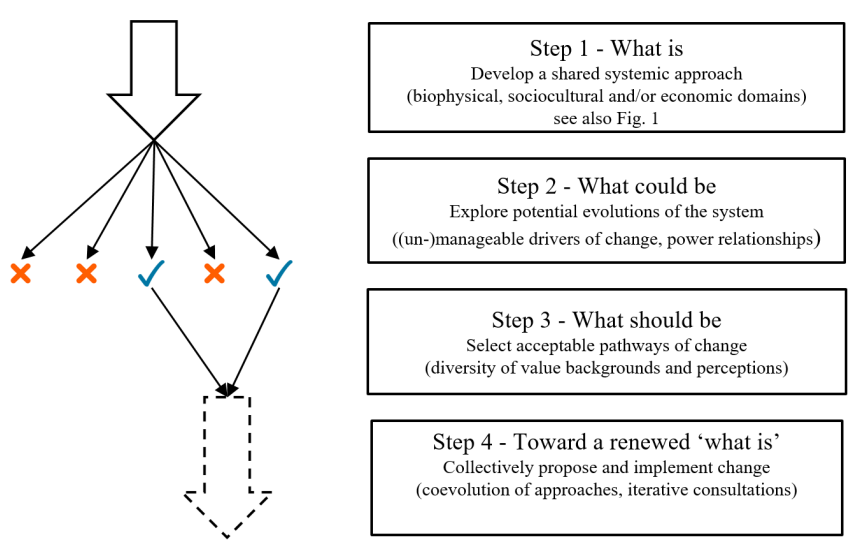

Expected outcomes $\rightarrow$ Assessment of current supply and
demand of ES bundles

$\rightarrow$ Identification of plausible transformations of the agroecosystem and of related ES bundles

$\rightarrow$ Selection of the most acceptable pathway in terms of ES potential and values held

$\rightarrow$ Implement selected update of the supply and demand of ES bundles
Example

Assessment of a current issue of low erosion control

Scenario A - transformation toward hedge planting Scenario B - transformation toward no-till agriculture

Choice of scenario $B$ - identified as having locally the highest potential in terms of erosion control and most valued by stakeholders

Implementation of no till agriculture on the ground $\rightarrow$ modification of other ES flows, e.g., provides a soil favorable to micro-organisms and enhances the ES 'soil formation trade-offs inherent to the management of social-ecological (agro) ecosystems (Armitage et al. 2008, Galafassi et al. 2017). The multiple levels of transformation enabled by such social learning (Pahl-Wostl 2009) are a core strategic process of integrated ES valuations (Jacobs et al. 2016).

An increasing amount of ES research focuses on agroecosystems (e.g., Sandhu et al. 2010, Barral et al. 2015, Fan et al. 2016). Interestingly, these remain restricted to the assessment of ES delivery under distinct agricultural scenarios, but lack any discussion on how to reach them, i.e., how to implement an agroecological transition on the ground.

We believe integrated ES valuations can be used to steer agroecological transitions as they can interestingly support the establishment of effective emergence of communities of practice (Duru and Thérond 2015). Like Barnaud et al. (2018), we take a constructivist perspective considering that ES are social constructions, representing inherently subjective perceptions of human - nature relationships. By allowing divergent viewpoints to be documented and fostering shared understanding and conceptualizations of the systems, participative and multifaceted ES valuations hold several relevant attributes to successfully address wicked problems, such as the inclusion of social values, the reinforcement of mutual capacity building, or the establishment of trust among partners (Davies et al. 2015).

\section{A FOUR-STEP ECOSYSTEM SERVICES ASSESSMENT FRAMEWORK FOR AGROECOLOGICAL TRANSITIONS IN PRACTICE}

In this section, we develop a four-step methodological framework to understand and steer an agroecological transition based on an integrated ES assessment (Fig. 1). This framework has been proposed building on ongoing related research, in particular on the "Farms for future" project led by the TERRA Research Centre (funded by the Belgian National Funds for Science Researche (FNRS), led by the TERRA research centre, Gembloux Agro-bio Tech, University of Liège (2016-2019)) that aims at understanding the impacts of agroecological farming systems on the delivery of ES as well as on ES beneficiaries. Our proposal is also rooted in sustainability analyses (e.g., Ostrom 2009, Ban et al. 2013) and builds on current work on integrated ES valuation (Jacobs et al. 2016). It echoes recent progress in the implementation of ES-based approaches to multifunctional and complex social-ecological systems (e.g., Cowling et al. 2008, Mastrangelo et al. 2014). This framework is foreseen to be trialled on forthcoming research-action projects aiming at understanding and supporting agroecological transitions in real-world situations.

We suggest an iterative framework, as ES flows are likely to follow nonlinear responses from the onset of an agroecological transition, and as learning and enhanced mutual understanding between different stakeholders may also change how some services are understood and valued. This process is by essence rooted in a science-practice partnership "that enables cogeneration of knowledge, which is both user-inspired and userrelevant" (Förtser et al. 2015). Agroecology offers a highly favorable venue for practicing science with people (CuéllarPadilla and Calle-Collado 2011) and in accordance, the path proposed by our framework requires a high level of participation from stakeholders. Many experiments worldwide have linked participatory action research and agroecological transitions (Levidow et al. 2014, Méndez et al. 2017). There is probably no silver bullet in the way these processes should actually be aligned and practically implemented: a necessary correlate of engaging in a coconstructed process is to tailor the methods and tools used to the local context and to the specific objectives of the stakeholders engaged (Funtowicz and Ravetz 1993). As a consequence, we do not provide in our framework a ready-made solution for practical implementation of the participatory process. However, an increasing number of methods are available for identifying and involving stakeholders as well as for combining environmental and social insights (see among others, Reed et al. 2009, Cuellar-Padilla and Calle-Collado 2011, Bagstad et al. 2013, Förster et al. 2015). As Jacobs et al. (2017) demonstrated, different valuation methods need to be combined to elicit the main value dimensions of nature (nonanthropocentric, relational, and instrumental). Biophysical modeling processes can be used to represent, e.g., through maps, the ability of landscapes to supply given ES. Field surveys and experiments might help ensure the robustness of these outputs and also comfort stakeholders 
Fig. 2. A multilevel (L) methodology to allow a better understanding of agroecological practices and their impacts on ES flows and underlying processes. Measurements can be done in agroecological parcels and conventional ones in order to have a reference point. Examples of indicators are provided on the right.

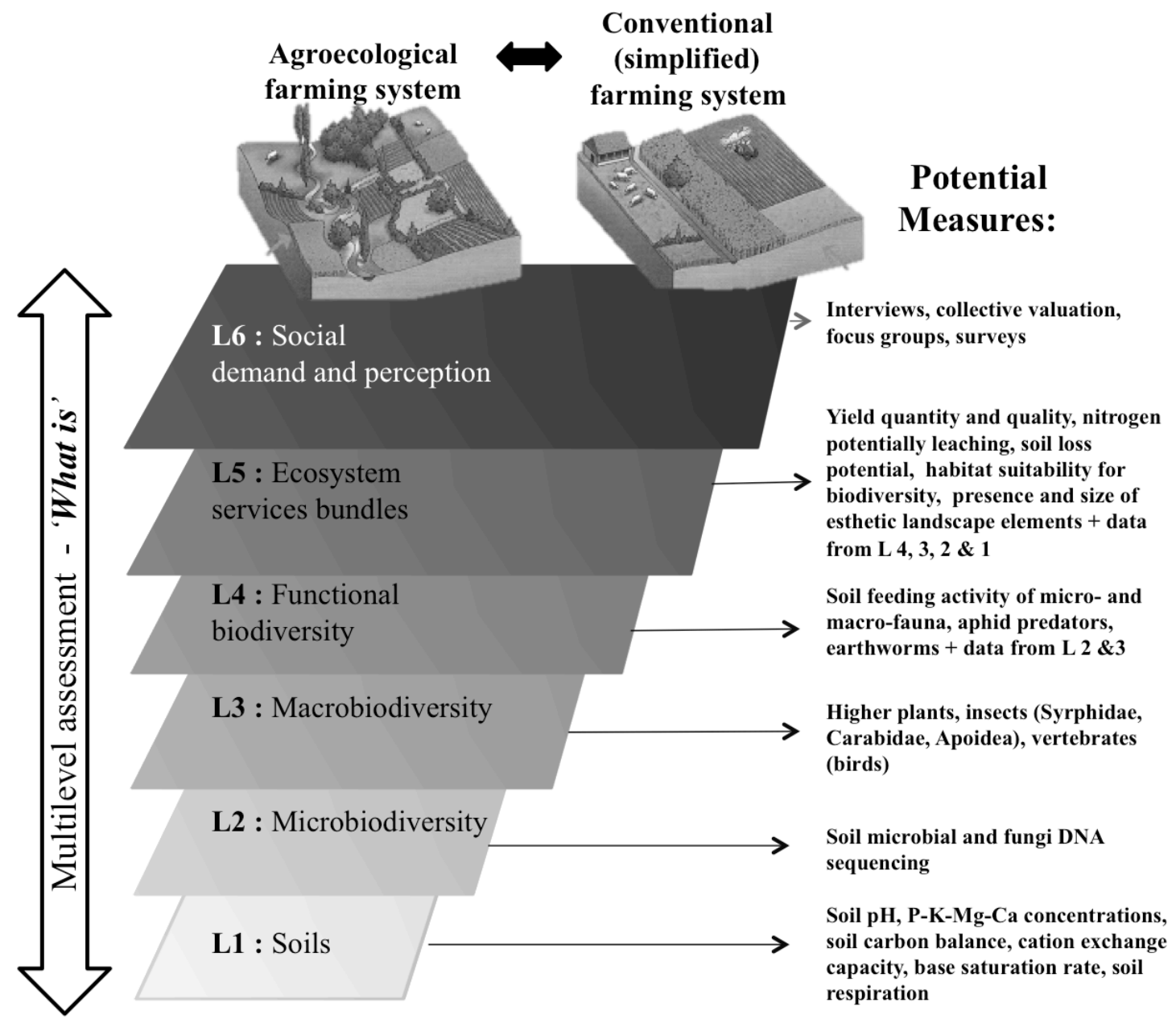

regarding the feasibility of the agroecological transition. In turn, ES maps can usefully support discussions on the necessary conditions for sustaining multiple ES, in terms of management practices, landscape features, and environmental supporting conditions. Among interesting tools to articulate stakeholders' perceptions of a complex system, participative mental models (Etienne et al. 2011, Moreno et al. 2014), influence networks (Crouzat et al. 2016), companion modeling (Etienne 2014), and social network analysis (Hicks et al. 2013) could be mobilized throughout the steps of our framework to come out with collective representations of the agroecosystems and of their futures. Although mobilizing such a spectrum of methods may seem demanding, it has been shown that performing such an integrated valuation does not necessarily entail more resources, as for every value dimension, methods with relatively low requirements are available (Jacobs et al. 2017).
Step 1. Building a common understanding of the current situation ("what is")

As a first step toward steering change, reaching a common understanding or shared vision of the current system appears an essential prerequisite. Integrated ES assessments, by informing different value-domains, namely biophysical, sociocultural, and/ or economic domains (Martín-López et al. 2014), can help develop a common systemic approach to the agricultural matrix.

In Fig. 2, we propose a methodology to practically improve the knowledge and understanding of an agroecosystem. The objective here is for all stakeholders involved in the agroecological transition to build a shared understanding of the current state before heading toward discussions and decisions on future states of the system. This multilevel framework does not mean that levels have to be addressed following a specific order. In fact, the biophysical-oriented assessments (levels 1-5) should be embedded in the social valuation (level 6) (Dendoncker et al. 2013, 
Table 1. Example of how information gathered at different levels can feed integrated valuation of ES

\begin{tabular}{|c|c|c|c|}
\hline Category & ES & Indicator & Level \\
\hline \multirow[t]{2}{*}{ Provisioning } & \multirow[t]{2}{*}{ Commercial crop production } & Yield (harvest on a known surface) & Ecosystem services \\
\hline & & Quality & Ecosystem services \\
\hline \multirow{18}{*}{ Regulation } & Soil formation & Earthworm density, biomass, maturity, and diversity & Macrobiodiversity \\
\hline & \multirow[t]{3}{*}{ Nutrient regulation } & Organic matter degration by macro-organisms & Functional biodiversity \\
\hline & & Organic matter degration by micro-organisms & Functional biodiversity \\
\hline & & Nitrogen potentially leaching & Ecosystem services \\
\hline & \multirow[t]{4}{*}{ Soil fertility and carbon cycle } & Cation exchange capacity and base saturation rate & \multirow[t]{4}{*}{ Soils } \\
\hline & & Total organic carbon content & \\
\hline & & Labile and stable carbon pool & \\
\hline & & Soil respiration & \\
\hline & \multirow[t]{2}{*}{ Pest control } & Parasitism rate & Functional biodiversity \\
\hline & & Predation rate & Functional biodiversity \\
\hline & \multirow[t]{2}{*}{ Pollination } & Pollinators density & Macrobiodiversity \\
\hline & & Pollinator diversity & Macrobiodiversity \\
\hline & \multirow[t]{2}{*}{ Erosion protection } & Soil aggregate stability & Ecosystem services \\
\hline & & Soil loss potential & Ecosystem services \\
\hline & \multirow[t]{4}{*}{ Habitat quality for biodiversity } & Carabid bettle density & Macrobiodiversity \\
\hline & & Carabid beetle diversity & Macrobiodiversity \\
\hline & & Micro-organisms populations (DNA sequencing) & Micro-biodiversity \\
\hline & & Habitat suitability and connectivity & Ecosystem services \\
\hline \multirow[t]{4}{*}{ Cultural } & \multirow[t]{2}{*}{ Physical experiences } & Presence of landscape elements & Ecosystem services \\
\hline & & Size of landscape elements & Ecosystem services \\
\hline & \multirow[t]{2}{*}{ Education } & Farm visits (interviews) & Ecosystem services \\
\hline & & Training sessions (interviews) & Ecosystem services \\
\hline
\end{tabular}

Spangenberg et al. 2014, Jacobs et al. 2016). Social valuations identify stakeholders affecting or affected by ES flows, gather information on what and how stakeholders value ES ("the ES demand"), and analyze mental frameworks used when valuing ES (Fontaine et al. 2014). Stakeholders' selection is a critical aspect as it directly influences outcomes of their consultation. Carrying out a stakeholder analysis, as a preliminary step to the assessment, seems necessary to include representatives of all legitimate stakeholders (Grant and Curtis 2004, Reed et al. 2009). Identifying context-relevant ES guides ES assessments toward specific natural resource management issues. As ecological functions only become ES when someone values them or benefits from them, identifying key ES to sustain involves subjective judgments (Förster et al. 2015). To capture these judgments, it is thus critical to involve multiple knowledge sources by including stakeholders in the process of identifying and prioritizing ES (Chan et al. 2012, Spangenberg et al. 2015, Mascarenhas et al. 2016). Participatory ES identification and selection are increasingly implemented (e.g., Bryan et al. 2010, Fontaine et al. 2014), and some guidelines are starting to emerge on this specific step (Mascarenhas et al. 2016; F. Boeraeve et al., unpublished manuscript).

These various levels of study are all related to a set of suggested measurements. Importantly, these levels of study all relate to different spatial scales of measurement (parcel - e.g., soil data, farm - e.g., yield, and landscape scale - e.g., ES indicators of landscape connectivity, cultural ES). They feed each other by providing underlying knowledge and understanding. For example, soil data (level 1) partly explain population assemblages of soil micro- (level 2) and macrobiodiversity (level 3). Soil biodiversity in turn influences ecological processes and ES flows (level 5) such as soil structure and fertility, plant growth, and pathogen protection (Maron et al. 2011). Many macrobiodiversity groups (level 3), such as insects (Syrphidae, Carabidae, Apoidea) and vertebrates (e.g., birds) are highly sensitive to their environment and thus represent good indicators of habitat quality and its relationship to agricultural practices. From these groups, functional agrobiodiversity (level 4) can be identified, such as predators, pollinators, decomposers, etc. Additional measures can be implemented to assess functional impacts of these groups like measuring soil decomposition rates, assessing pest abundance, etc. Information gathered from the four first levels can then be translated into ES indicators (Table 1). For instance, some soil physico-chemical properties (C balance, CEC, base saturation rate; level 1) hint at the ES "soil fertility;" or the presence of "aphid predators" (level 4) can be translated into an indicator of the ES "biological pest control." Additional indicators have to be collected specifically like "potential $\mathrm{N}$ leaching" to assess ES "nutrient regulation." Supplementary indicators are also gathered for cultural ES, which are assessed based on the presence of landscape elements known for being appreciated, thus harboring esthetic values (e.g., tree lines, forest patches). Information on individual ES can then be combined to characterize ES bundles typical of different management practices and ecological contexts.

At the broadest level (level 6), a social ES valuation is carried out. This provides a thorough understanding regarding socioeconomic values borne by the different stakeholders (also referred to as the "ES demand") and how they relate to the idea of an agroecological transition. Including stakeholders' values in the assessment and decision process allows accounting for power asymmetries and increases chances of equity (Felipe-Lucia et al. 2015). The method can rely on individual interviews and collective valuation (e.g., focus groups, participative workshops). Individual interviews put forward the divergence of social values among stakeholders, and the collective valuation, through deliberation, includes reciprocal and altruistic attitudes within the valuation (Sen 1995, Vatn 2005). 
In theory, such assessment would ideally be carried out in the same farming systems and parcels before and after the agroecological transition to assess its impact directly. However, as such diachronic assessment is rarely feasible, assessments can be carried out concomitantly in agroecological parcels and farming systems and in conventional ones. Doing so, we have to keep in mind that comparison stricto sensu between parcels is highly sensitive to the technical history of the parcel. To avoid ignoring this, the analysis should focus on the relative distances or variances between the different elements and not on comparing means. "Compared" parcels should ideally share the same crop type, soil type, and landscape structure (which is not inherent to the practices, e.g., a nearby wood) in order to minimize potential bias, and technical itineraries of each studied parcel should be scrutinized to identify potential outliers.

As stated above, bundles of ES can be identified (Mouchet et al. 2014) to highlight the characteristic patterns of associations representative of various social-ecological subsystems (e.g., Crouzat et al. 2015). This appears of critical importance as ES are used, affected and valued differently by stakeholders, inducing the necessity to consider jointly multiple ES (Förtser et al. 2015). Overall, integrated ES valuations should be used to characterize the distinct social and ecological contexts that coexist throughout the landscape and that shape the current bundles of ES supplied and demanded.

\section{Step 2. Exploring a diversity of futures ("what could be")}

Once a systemic vision of the current agricultural matrix is reached, plausible trajectories of change can be elaborated. Scenario approaches are an increasingly popular tool that can help span the alternative reachable futures of social-ecological systems in a collaborative way (see Oteros-Rozas et al. 2015 for a recent review). Participatory scenario making encourages complexity thinking (e.g., Waylen et al. 2015). This appears necessary to account jointly for supply and demand facets of ES assessed in Step 1 and implicated in trade-offs and synergies analyses (Mouchet et al. 2014, Crouzat et al. 2016) to thereby anticipate the implications of changes from local and global drivers of and threats to ES identified in Step 1. For instance, changes in fertilization management or in types of crops can modify the amount and temporality of nitrogen and pesticide leaching, thereby impacting the ability of landscapes to maintain water quality as well as their esthetics. Such changes in these two services can be assessed, e.g., through computer-based maps that can be closely developed and analyzed with stakeholders to identify the ways multiple ES could be affected by different management options in the future (e.g., Reed et al. 2009). Alternatively, stakeholders confronted with the will to enhance soil erosion control might propose different scenarios, including a no-till option and an increase in hedge density (Fig. 1), both of which are relevant drivers of erosion control. As bundles of ES discriminate different agricultural management trajectories, they appear to be a relevant object to trace the expected outcomes of changes in agricultural management strategies and discuss the possible evolutions of the landscape. In this step, scenarios should not only consist of proposing adaptations of current practices but should also allow major changes to be discussed, including changes in paradigm. Diachronic feedbacks from other experiments, although still too scarce (Dendoncker and Crouzat 2018), could be used to help grasp the diversity and magnitude of transformations that could be locally projected. Among necessary features to identify, manageable drivers of change should be pinpointed, as well as the existing influence relationships among actors (Felipe-Lucia et al. 2015) and their consequences on sustainability transition. Stakeholders could be invited to identify the key bottlenecks that might hinder the agroecological transition, considering among other issues knowledge, technical options, social acceptability, as well as administrative or regulatory frames. Importantly also, the influence of external economic dynamics and of internal cultural drivers such as informal institutions (Pahl-Wostl 2009) should be acknowledged to ensure the relevance of proposed alternatives.

\section{Step 3. Selecting acceptable pathways of change ("what should be")}

As mentioned previously, stakeholders hold varying perceptions and expectations regarding the current and ideal agricultural management(s) of their territory. Steering the agroecological transition implies managing current and emergent trade-offs among ES to orientate the system toward its expected state. In addition to evaluating what is feasible, an important effort of the integrated ES valuation should be dedicated to making explicit what is desirable and for whom (Cote and Nightingale 2012, Davies et al. 2015). In other words, it appears necessary to keep space for subjective and emotional dimensions as negotiating the agroecological transition is a highly normative political process (Wezel et al. 2009). The characterization of ES supply and demand from Step 1 will contribute to making explicit social priorities. Once the diversity of values is acknowledged, the overall legitimacy of the integrated ES valuation process is strengthened (Cash et al. 2003). The objective of this step is to identify diverse viewpoints and common ground among these that might become a basis for a broadly accepted normative vision of the studied agroecosystem. This objective can be attained by individual and collective consultation of stakeholders aimed at revealing their desired vision of the agroecosystem in the light of the information gathered in Step 2. For instance, in the objective of reinforcing the erosion control service, stakeholders might prefer turning to no-till agricultural practices rather than to increasing the density of hedges (Fig. 1). Indeed, this scenario might seem more appealing and efficient locally, regarding topographic conditions, farm equipment, or economic viability.

\section{Step 4. Implementing acceptable pathways of change (toward a renewed "what is")}

The objective of this step is to turn into practice the options for changes discussed and selected previously. Bluntly, Step 4 is the time for operationalization on the ground of renewed practices, organizational structures, and management methods. Steering the agroecological transition requires a "process-oriented and goalseeking approach" to operationalize the changes projected (Duru and Thérond, 2015). Changes on targeted ES might have an influence on other ES, reinforcing the necessity to consider them jointly as bundles. For instance, changes in erosion control induced by no-till practices will probably affect, at least, the service of soil formation by inducing more favorable conditions for soil microorganisms (Fig. 1). Integrated ES valuations offer a relevant framework for identifying the necessary steps of change by including both the ecological and social aspects of the transition management. Indeed, if technical changes are to be accepted and implemented, cultural evolutions are also necessary 
and need to be negotiated and prepared. Feedbacks from the social system on the ecological system, including governance effects, can be adequately anticipated by the ES valuation. Differentiated approaches of change can coevolve in the territory and gather subgroups of interested stakeholders. For example, technical aspects of the agroecological transition can be discussed by some (e.g., on reduced or no-till technologies, Fig.1), whereas others can target their efforts to structuring local distribution chains. There is probably no one-fits-all solution, so stakeholders should be stimulated by iterative coconstructed meetings to propose innovative and locally adapted solutions (Galafassi et al. 2017). Once changes are initiated, integrated ES valuations offer an interesting opportunity for monitoring the agroecological transition, as ES proxies can be tracked and social perceptions of changes in ES bundles can be iteratively assessed.

\section{Ecosystem services and agroecology: limitations of the ecosystem} services approach

In general, integrated valuation of ES faces a series of challenges, including fragmented policy and governance fields to target, fragmented science fields to combine for comprehensive assessments, and difficulty in accounting for equity issues in the context of power imbalances (see Jacobs et al. 2016 for a broader discussion).

The way ES assessments are designed and the specific issues they address are critical for engaging in collective transformation of agroecosystems. The ES approach, although rather holistic, may omit certain aspects, such as heritage, historic values, health, farmers' salary, local employment, human rights, etc. (Mills 2012).

Scientists must thus take a step back to grasp human well-being not only based on ES data. A quantity of ES flow may not be a good indicator of well-being as there may be no demand for it, or it may be unevenly shared among beneficiaries (Collins et al. 2010). Finally, ecological thresholds should always be as much as possible considered in such an integrated approach (Maron et al. 2017).

Even if various types of values are acknowledged, the issue of how to make the final decision remains. Valuation exercises always take place in a given institutional setting (Vatn 2005, Dendoncker et al. 2013). Because environmental resources are often common and complex goods, this institutional setting should ideally favor social rationality and communicative action, ensuring that a societal perspective is taken and that the procedure must be able to treat weakly comparable or incommensurable value dimensions (Vatn 2005, Martinez-Alier 1998). At the global level, some authors argue that new institutions and more resources devoted to environmental governance are needed (Norgaard 2010).

At the local level, however, the increase in place-based actions and public support for change raises hope. Arguably, place-based, territorial applications of transformative research could provoke local regime shifts in agriculture. Coconstructed actions between science, society, and policy may lead to greater changes. The operational potential of integrative and inclusive ES assessments to foster the transition to agroecology remains, however, to be strengthened.

\section{CONCLUSION}

In seeking transition of prevailing farming methods to agroecology, sustainable agricultural systems will need to be designed for autonomy, resilience, and diversity. Because it may bring together a broad range of local actors who defend disparate sets of values, integrated valuation of ES has the potential to serve as a tool for diverse actors to develop a shared knowledge base to better understand stakeholders' expectations and constraints, to recognize shared priorities, and for concerted action. Although there are local cases where ES assessments have led to increased ES delivery and social learning, it has not been demonstrated that ES assessments could lead to more systemic changes in agroecosystems, by increasing economic efficiency, improving the environment, but also increasing equity by accounting for and dealing with power asymmetries. Moreover, at the global level, it is likely that for agroecological systems to replace the current dominant regime, wider institutional changes at larger scales are to be implemented, and many barriers to change must be overcome. However, by systematically adopting integrated and inclusive ES assessments at the local scale, crucial information on how ES delivery helps good functioning of agroecological systems and on how the latter deliver ES to local communities can be gathered and further mobilized to steer agroecological transitions for sustainability. Further research should review, gather evidence from, and communicate about stories of success and failures to draw lessons on how to accelerate these transitions.

Responses to this article can be read online at: http://www.ecologyandsociety.org/issues/responses. $\mathrm{php} / 9843$

\section{LITERATURE CITED}

Adhikari, K., and A. E. Hartemink. 2016. Linking soils to ecosystem services - a global review. Geoderma 262:101-111. http://dx.doi.org/10.1016/j.geoderma.2015.08.009

Altieri, M. A. 1989. Agroecology: a new research and development paradigm for world agriculture. Agriculture, Ecosystems and Environment 27(1-4):37-46. http://dx.doi.org/ https://doi.org/10.1016/B978-0-444-88610-1.50006-1

Armitage, D., M. Marschke, and R. Plummer. 2008. Adaptive comanagement and the paradox of learning. Global Environmental Change 18(1):86-98. http://dx.doi.org/10.1016/j.gloenvcha.2007.07.002

Bagstad, K. J., D. J. Semmens, S. Waage, and R. Winthrop. 2013. A comparative assessment of decision-support tools for ecosystem services quantification and valuation. Ecosystem Services 5:27-39. http://dx.doi.org/10.1016/j.ecoser.2013.07.004

Ban, N. C., M. Mills, J. Tam, C. C. Hicks, S. Klain, N. Stoeckl, M.C. Bottrill, J. Levine, R.L. Pressey, T. Satterfield, and K M. A. Chan. 2013. A social-ecological approach to conservation planning: embedding social considerations. Frontiers in Ecology and the Environment 11:194-202. http://dx.doi.org/10.1890/110205

Banerjee, S., S. Secchi, J. Fargione, S. Polasky, and S. Kraft. 2013. How to sell ecosystem services: a guide for designing new markets. Frontiers in Ecology and the Environment 11: 297-304. http://dx. doi.org/10.1890/120044 
Barnaud, C., and M. Antona. 2014. Deconstructing ecosystem services: uncertainties and controversies around a socially constructed concept. Geoforum 56:113-123. http://dx.doi. org/10.1016/j.geoforum.2014.07.003

Barnaud C., E. Corbera, R. Muradian, N. Salliou, C. Sirami, A. Vialatte, J.-P. Choisis, N. Dendoncker, R. Mathevet, C. Moreau, V. Reyes-Garcia, M. Boada, M. Deconchat, C. Cibien, S. Garnier, R. Maneja, and M. Antona. 2017. Ecosystem services, social interdependencies and collective action: a conceptual framework. Ecology and Society, this issue.

Barral, M. P., J. M. Rey Benayas, P. Meli, and N. O. Maceira. 2015. Quantifying the impacts of ecological restoration on biodiversity and ecosystem services in agroecosystems: a global meta-analysis. Agriculture, Ecosystems and Environment 202:223231. http://dx.doi.org/10.1016/j.agee.2015.01.009

Boeraeve, F., N. Dendoncker, S. Jacobs, E. Gomez Baggethun, and M. Dufrêne. 2015. How (not) to perform ecosystem service valuations: pricing gorillas in the mist. Biodiversity and Conservation 24(1):187-197. http://dx.doi.org/10.1007/s10531-014-0829-9

Bohlen, P., S. Lynch, L. Shabman, M. Clark, S. Shukla, and H. Swain. 2009. Paying for environmental services from agricultural lands: an example from the northern Everglades. Frontiers in Ecology and the Environment 7(1):46-55. http://dx.doi. org/10.1890/080107

Boogaard, B. K., B. B. Bock, S. J. Oosting, J. S. C. Wiskerke, and A. J. Zijpp. 2010. Social acceptance of dairy farming: the ambivalence between the two faces of modernity. Journal of Agricultural and Environmental Ethics 24(3):259-282.

Bryan, B. A., C. M. Raymond, N. D. Crossman, and D. H. Macdonald. 2010. Targeting the management of ecosystem services based on social values: where, what, and how? Landscape and Urban Planning 97(2):111-122. http://dx.doi.org/10.1016/j. landurbplan.2010.05.002

Caron, P., E. Biénabe, and E. Hainzelin. 2014. Making transition towards ecological intensification of agriculture a reality: the gaps in and the role of scientific knowledge. Current Opinion in Environmental Sustainability 8:44-52. http://dx.doi.org/10.1016/ j.cosust.2014.08.004

Cash, D. W., W. C. Clark, F. Alcock, N. M. Dickson, N. Eckley, D. H. Guston, and R. B. Mitchell. 2003. Knowledge systems for sustainable development. Proceedings of the National Academy of Sciences 100(14):8086-8091. http://dx.doi.org/10.1073/ pnas. 1231332100

Chan, K. M. A., A. D. Guerry, P. Balvanera, S. Klein, T. Satterfield, X. Basurto, A. Bostrom, R. Chuenpagdee, R. Gould, B. S. Halpern, N. Hannahs, J. Levine, B. Norton, M. Ruckelshaus, R. Russell, J. Tam, and U. Woodside. 2012. Where are cultural and social in ecosystem services: a framework for constructive engagement. BioScience 6(8):744-756. http://dx.doi.org/10.1525/ bio.2012.62.8.7

Collins, S. L., S. R. Carpenter, S. M. Swinton, D. E. Orenstein, D. L. Childers, T. L. Gragson, N. B. Grimm, J. M. Grove, S. L. Harlan, J. P. Kaye, A. K. Knapp, G. P. Kofinas, J. J. Magnuson, W. H. McDowell, J. M. Melack, L. A. Ogden, G. P. Robertson, M. D. Smith, and A. C. Whitmer. 2010. An integrated conceptual framework for long-term social-ecological research. Frontiers in Ecology and the Environment 9(6):351-357. http://dx.doi. org/10.1890/100068

Costa, C., J. García-Lestón, S. Costa, P. Coelho, S. Silva, M. Pingarilho, V. Valdiglesias, F. Mattei, V. Dall'Armi, S. Bonassi, B. Laffon, J. Snawder, and J. P. Teixeira. 2014. Is organic farming safer to farmers' health? A comparison between organic and traditional farming. Toxicology Letters 230(2):166-176. http://dx. doi.org/10.1016/j.toxlet.2014.02.011

Costanza, R., R. de Groot, P. Sutton, S. van der Ploeg, S. J. Anderson, I. Kubiszewski, S. Farber, and R. K. Turner. 2014. Changes in the global value of ecosystem services. Global Environmental Change 26:152-158. http://dx.doi.org/10.1016/j. gloenvcha.2014.04.002

Cote, M., and A. J. Nightingale. 2012. Resilience thinking meets social theory: situating social change in socio-ecological systems (SES) research. Progress in Human Geography 36(4):475-489. http://dx.doi.org/10.1177/0309132511425708

Crouzat, E., B. Martín-López, F. Turkelboom, and S. Lavorel. 2016. Disentangling trade-offs and synergies around ecosystem services with the influence network framework: illustration from a consultative process over the French Alps. Ecology and Society 21(2). http://dx.doi.org/10.5751/ES-08494-210232

Crouzat, E., M. Mouchet, F. Turkelboom, C. Byczek, J. Meersmans, F. Berger, and S. Lavorel. 2015. Assessing bundles of ecosystem services from regional to landscape scale: insights from the French Alps. Journal of Applied Ecology 52(5):1145-1155. http://dx.doi.org/10.1111/1365-2664.12502

Cowling, R. M., B. Egoh, A. T. Knight, P. J. O’Farrell, B. Reyers, M. Rouget, D. J. Roux, A. Welz, and A. Wilhelm-Rechman. 2008. An operational model for mainstreaming ecosystem services for implementation. Proceedings of the National Academy of Sciences 105:9483-9488. http://dx.doi.org/10.1073/pnas.0706559105

Cuéllar-Padilla, M., and Á Calle-Collado. 2011. Can we find solutions with people? Participatory action research with small organic producers in Andalusia. Journal of Rural Studies 27 (4):372-383. http://dx.doi.org/10.1016/j.jrurstud.2011.08.004

Dale, V. H., and S. Polasky. 2007. Measures of the effects of agricultural practices on ecosystem services. Ecological Economics 64(2):286-296. http://dx.doi.org/10.1016/j. ecolecon.2007.05.009

Davies, K. K., K. T. Fisher, M. E. Dickson, S. F. Thrush, and R. Le Heron. 2015. Improving ecosystem service frameworks to address wicked problems. Ecology and Society 20(2). http://dx. doi.org/10.5751/ES-07581-200237

Davila, F., and R. Dyball. 2018. Food systems and human ecology: an overview. Pages 183-211 in A. König and J. Ravetz, editors. Sustainability science as social learning process. Routledge, London, UK. http://dx.doi.org/10.9774/ GLEAF.9781315620329 11

Dendoncker, N., and E. Crouzat. 2018. Can ecosystem services help the new agricultural transition? Pages 169-183 in A. König and J. Ravetz, editors. Sustainability science as social learning process. Routledge, London, UK. http://dx.doi.org/https://doi. org/10.9774/GLEAF.9781315620329 10 
Dendoncker, N., H. Keune, S. Jacobs, and E. Gomez-Baggethun. 2013. Inclusive ecosystem services valuation. Pages 3-12 in S. Jacobs, N. Dendoncker, and H. Keune. Ecosystem services: global issues, local practices. Elsevier, New York, New York, USA. http:// dx.doi.org/10.1016/B978-0-12-419964-4.00001-9

De Schutter, O. 2014. Report of the Special Rapporteur on the right to food. Final report: the transformative potential of the right to food. Human Right Council, General Assembly, United Nations, New York, New York, USA.

Díaz, S., S. Demissew, C. Joly, W. M. Lonsdale, and A. Larigauderie. 2015. A rosetta stone for nature's benefits to people. PLoS Biology 13(1): e1002040. http://dx.doi.org/10.1371/journal. pbio. 1002040

Donald, P. F., F. J. Sanderson, I. J. Burfield, and F. P. van Bommel. 2006. Further evidence of continent-wide impacts of agricultural intensification on European farmland birds, 1990-2000. Agriculture, Ecosystems and Environment 116:189-196. http://dx. doi.org/https://doi.org/10.1016/j.agee.2006.02.007

Duru, M., and O. Thérond. 2015. Designing agroecological transitions: a review. Agronomy for Sustainable Development 35 (4): 1237-1257. http://dx.doi.org/10.1007/s13593-015-0318-x

Engel, S., S. Pagiola, and S. Wunder. 2008. Designing payments for environmental services in theory and practice: an overview of the issues. Ecological Economics 65:663-674. http://dx.doi. org/10.1016/j.ecolecon.2008.03.011

Etienne, M., editor. 2014. Companion modelling. A participatory approach to support sustainable development. Springer, Dordrecht, The Netherlands.

Etienne, M., D. R. Du Toit, and S. Pollard. 2011. ARDI: a coconstruction method for participatory modeling in natural resources management. Ecology and Society 16(1):44. http://dx. doi.org/10.5751/ES-03748-160144

Fan, F., C. B. Henriksen, and J. Porter. 2016. Valuation of ecosystem services in organic cereal crop production systems with different management practices in relation to organic matter input. Ecosystem Services 22:117-127. http://dx.doi.org/10.1016/ j.ecoser.2016.10.007

Felipe-Lucia, M. R., B. Martín-López, S. Lavorel, L. BerraqueroDíaz, J. Escalera-Reyes, and F. A. Comín. 2015. Ecosystem services flows: why stakeholders' power relationships matter. PloS One 10(7): e0132232. http://dx.doi.org/10.1371/journal.pone.0132232

Fisher, B., R. K. Turner, and P. Morling. 2009. Defining and classifying ecosystem services for decision-making. Ecological Economics 68:643-653. http://dx.doi.org/10.1016/j.ecolecon.2008.09.014

Fontaine, C. M., N. Dendoncker, R. De Vreese, I. Jacquemin, A. Marek, A. van Herzele, G. Devillet, D. Mortelmans, and L. François. 2014. Towards participatory integrated valuation and modelling of ecosystem services under land-use change. Journal of Land Use Science 9(3):278-303. http://dx.doi. org/10.1080/1747423X.2013.786150

Förster, J., J. Barkmann, R. Fricke, S. Hotes, M. Kleyer, S. Kobbe, D. Kübler, C. Rumbaur, M. Siegmund-Schultze, R. Seppelt, J. Settele, J. H. Spangenberg, V. Tekken, T. Václavík, and H. Wittmer. 2015. Assessing ecosystem services for informing land- use decisions: a problem-oriented approach. Ecology and Society 20(3):31. http://dx.doi.org/10.5751/ES-07804-200331

Funtowicz, S. O., and J. R. Ravetz. 1993. Science for the postnormal age. Futures 25(7):739-755. http://dx.doi.org/https://doi. org/10.1016/0016-3287(93)90022-L

Galafassi, D., T. Daw, L. Munyi, K. Brown, C. Barnaud, and I. Fazey. 2017. Learning about social-ecological trade-offs. Ecology and Society 22(1): 2. http://dx.doi.org/10.5751/ES-08920-220102

Garbach, K., J. Milder, F. DeClerck, M. Montenegro de Wit, L. Driscoll, and B. Gemmill-Herren. 2017. Examining multifunctionality for crop yield and ecosystem services in five systems of agroecological intensification. International Journal of Agricultural Sustainability 15(1):11-28. http://dx.doi. org/10.1080/14735903.2016.1174810

Gelfand, I., and G. P. Robertson. 2015. Mitigation of greenhouse gases in agricultural ecosystems. Pages 419-458 in S. K. Hamilton, J. E. Doll, and G. P. Robertson, editors. The ecology of agricultural landscapes: long-term research on the path to sustainability. LTER Series, Oxford University Press, New York, New York, USA.

Gliessman, S. R. 2009. The framework for conversion. Pages $3-$ 16 in S. R. Gliessman and M. Rosemeyer, editors. The conversion to sustainable agriculture: principles, processes, and practices, CRC Press, Boca Raton, Florida, USA. http://dx.doi.org/10.1201/97$\underline{81420003598-c 1}$

Gomez-Baggethun, E., B. Martin-Lopez, D. N. Barton, L. Braat, E. Kelemen, M. Garcia-Llorente, H. Saarikoski, and J. van den Bergh. 2014. State-of-the-art report on integrated valuation of ecosystem services. OpenNESS report EU FP7, European Commission, Brussels, Belgium.

Grant, A., and A. Curtis. 2004. Refining evaluation criteria for public participation using stakeholder perspectives of process and outcomes. Rural Society 14(2):142-162. http://dx.doi.org/10.5172/ rsj.351.14.2.142

Hein, L., K. van Koppen, R. S. De Groot, and E. C. van Ierland. 2006. Spatial scales, stakeholders and the valuation of ecosystem services. Ecological Economics 57(2):209-228. http://dx.doi. org/10.1016/j.ecolecon.2005.04.005

Hicks, C. C., N. A. J. Graham, and J. E. Cinner. 2013. Synergies and tradeoffs in how managers, scientists, and fishers value coral reef ecosystem services. Global Environmental Change 23(6):14441453. http://dx.doi.org/10.1016/j.gloenvcha.2013.07.028

Holt, A. R., A. Alix, A. Thompson, and L. Maltby. 2016. Food production, ecosystem services and biodiversity: we can't have it all everywhere. Science of the Total Environment 573:1422-1429. http://dx.doi.org/10.1016/j.scitotenv.2016.07.139

Jacobs, S., N. Dendoncker, and H. Keune. 2013. No root, no fruit - sustainability and ecosystem services. Pages XIX-XXVIII in S. Jacobs, N. Dendoncker, and H. Keune, editors. Ecosystem services: global issues, local practices. Elsevier, New York, New York, USA. http://dx.doi.org/https://doi.org/10.1016/ B978-0-12-419964-4.02002-3

Jacobs, S., N. Dendoncker, B. Martin-Lopez, D. N. Barton, E. Gomez-Baggethun, F. Boeraeve, F. McGrath, K. Vierikko, D. Geneletti, S. J. Katharina, N. Pipart, E. Primmer, P. Mederly, S. 
Schmidt, A. Aragão, H. Baral, R. Bark, T. Briceno, D. Brogna, P. Cabral, R. De Vreese, C. Liquete, H. Mueller, K. S.-H. Peh, A. Phelan, and A. Rincon. 2016. A new valuation school: integrating diverse values of nature in resource and land use decisions. Ecosystem Services 22:213-220. http://dx.doi.org/10.1016/j. ecoser.2016.11.007

Jacobs, S., B. Martín-López, D. N. Barton, R. Dunford, P. A. Harrison, E. Kelemen, H. Saarikoski, M. Termansen, M. GarcíaLlorente, E. Gómez-Baggethun, L. Kopperoinen, S. Luque, I. Palomo, J. A. Priess, G. M. Rusch, P. Tenerelli, F. Turkelboom, R. Demeyer, J. Hauck, H. Keune, and R. Smith. 2017. The means determine the end-pursuing integrated valuation in practice. Ecosystem Services, in press. http://dx.doi.org/10.1016/j. ecoser.2017.07.011

Kallis, G. E. Gomez-Baggethun, and C. Zografos. 2013. To value or not to value? That is not the question. Ecological Economics 94:97-105. http://dx.doi.org/10.1016/j.ecolecon.2013.07.002

Kremen, C., A. Iles, and C. Bacon. 2012. Diversified farming systems: an agroecological, systems-based alternative to modern industrial agriculture. Ecology and Society 17(4): 44. http://dx. doi.org/10.5751/ES-05103-170444

Kremen, C., and A. Miles. 2012. Ecosystem services in biologically diversified versus conventional farming systems: benefits, externalities, and trade-offs. Ecology and Society 17(4): 40. http://dx.doi.org/10.5751/ES-05035-170440

Landis, D. A. 2017. Designing agricultural landscapes for biodiversity-based ecosystem services. Basic and Applied Ecology 18:1-12. http://dx.doi.org/10.1016/j.baae.2016.07.005

Laurans, Y., and L. Mermet. 2014. Ecosystem services economic valuation, decision-support system or advocacy? Ecosystem Services 7:98-105. http://dx.doi.org/https://doi.org/10.1016/j. ecoser.2013.10.002

Laurans, Y., A. Rankovic, R. Billé, R. Pirard, and L. Mermet. 2013. Use of ecosystem services economic valuation for decisionmaking: questioning a literature blindspot. Journal of Environmental Management 119:208-219. http://dx.doi.org/10.1016/ j.jenvman.2013.01.008

Levidow, L., M. Pimbert, and G. Vanloqueren. 2014. Agroecological research: conforming - or transforming the dominant agro-food regime? Agroecology and Sustainable Food Systems 38(10):1127-1155. http://dx.doi.org/https://doi. org/10.1080/21683565.2014.951459

Lindemann-Matthies, P. R., B. Briegel, B. Schüpbach, and X. Junge. 2010. Aesthetic preference for a Swiss alpine landscape: the impact of different agricultural land-use with different biodiversity. Landscape and Urban Planning 98(2):99-109. http:// dx.doi.org/10.1016/j.landurbplan.2010.07.015

Maron, M., M. G. Mitchell, R. K. Runting, J. R. Rhodes, G. M. Mace, D. A. Keith, and J. E. Watson. 2017. Towards a threat assessment framework for ecosystem services. Trends in Ecology and Evolution 32(4):240-248. http://dx.doi.org/10.1016/j.tree.2016.12.011

Maron, P.-A., C. Mougel, and L. Ranjard. 2011. Soil microbial diversity: methodological strategy, spatial overview and functional interest. Comptes Rendus Biologies 334:403-411. http://dx.doi.org/10.1016/j.crvi.2010.12.003
Martín-López, B., E. Gómez-Baggethun, M. García-Llorente, and C. Montes. 2014. Trade-offs across value-domains in ecosystem services assessment. Ecological Indicators 37:220-228. http://dx.doi.org/10.1016/j.ecolind.2013.03.003

Martinez-Alier, J., G. Munda, and J. O'Neill. 1998. Weak comparability of values as a foundation for ecological economics. Ecological Economics 26(3):277-286. http://dx.doi.org/10.1016/ $\underline{\text { S0921-8009(97)00120-1 }}$

Mascarenhas, A., T. B. Ramos, D. Haase, and R. Santos. 2016. Participatory selection of ecosystem services for spatial planning: insights from the Lisbon Metropolitan Area, Portugal. Ecosystem Services 18:87-99. http://dx.doi.org/10.1016/j.ecoser.2016.02.011

Mastrangelo, M. E., F. Weyland, S. H. Villarino, M. P. Barral, L. Nahuelhual, and P. Laterra. 2014. Concepts and methods for landscape multifunctionality and a unifying framework based on ecosystem services. Landscape Ecology 29:345-358. http://dx.doi. org/10.1007/s10980-013-9959-9

Méndez, V. E., M. Caswell, S. R. Gliessman, and R. Cohen. 2017. Integrating agroecology and participatory action research (par): lessons from Central America. Sustainability 9(5):705. http://dx. doi.org/10.3390/su9050705

Merckx, T., and H. M. Pereira. 2015. Reshaping agrienvironmental subsidies: from marginal farming to large-scale rewilding. Basic and Applied Ecology 16(2):95-103. http://dx.doi. org/10.1016/j.baae.2014.12.003

Millenium Ecosystem Assessment (MEA). 2005. Ecosystems and human well-being: current states and trends. Island Press, Washington, D.C., USA.

Mills, J. 2012. Exploring the social benefits of agri-environment schemes in England. Journal of Rural Studies 28(4):612-621. http://dx.doi.org/10.1016/i.jrurstud.2012.08.001

Moreno, J., I. Palomo, J. Escalera, B. Martín-López, and C. Montes. 2014. Incorporating ecosystem services into ecosystembased management to deal with complexity: a participative mental model approach. Landscape Ecology 29(8):1407-1421. http://dx.doi.org/10.1007/s10980-014-0053-8

Mouchet, M. A., P. Lamarque, B. Martín-López, E. Crouzat, P. Gos, C. Byczek, and S. Lavorel. 2014. An interdisciplinary methodological guide for quantifying associations between ecosystem services. Global Environmental Change 28:298-308. http://dx.doi.org/10.1016/j.gloenvcha.2014.07.012

Muradian, R., M. Arsel, L. Pellegrini, F. Adaman, B. Aguilar, B. Agarwal, E. Corbera, D. Ezzine de Blas, J. Farley, G. Froger, E. Garcia-Frapolli, E. Gómez-Baggethun, J. Gowdy, N. Kosoy, J. F. Le Coq, P. Leroy, P. May, P. Méral, P. Mibielli, R.. Norgaard, B. Ozkaynak, U. Pascual, W. Pengue, M. Perez, D. Pesche, R. Pirard, J. Ramos-Martin, L. Rival, F. Saenz, G. van Hecken, A. Vatn, B. Vira, and K. Urama. 2013. Payments for ecosystem services and the fatal attraction of win-win solutions. Conservation Letters 6:274-279. http://dx.doi.org/10.1111/j.1755-263X.2012.00309.x

Norgaard, R. B. 2010. Ecosystem services: From eye-opening metaphor to complexity blinder. Ecological Economics 69:12191227 http://dx.doi.org/10.1016/j.ecolecon.2009.11.009 
Östman, Ö., B. Ekbom, and J. Bengtsson. 2003. Yield increase attributable to aphid predation by ground-living polyphagous natural enemies in spring barley in Sweden. Ecological Economics 45(1):149-158. http://dx.doi.org/10.1016/S0921-8009(03)00007-7

Ostrom, E. 2009. A general framework for analyzing sustainability of social-ecological systems. Science 325:419-422. http://dx.doi.org/10.1126/science.1172133

Oteros-Rozas, E., B. Martín-López, T. Daw, E.L. Bohensky, J. Butler, R. Hill, J. Martin-Ortega, A. Quinlan, F. Ravera, I. RuizMallén, and M. Thyresson. 2015. Participatory scenario planning in place-based social-ecological research: insights and experiences from 23 case studies. Ecology and Society 20(4): 32. http://dx.doi. org/https://doi.org/10.5751/ES-07985-200432

Pahl-Wostl, C. 2009. A conceptual framework for analysing adaptive capacity and multi-level learning processes in resource governance regimes. Global Environmental Change 19(3):354-365. http://dx.doi.org/10.1016/j.gloenvcha.2009.06.001

Pascual, U., and C. Perrings. 2007. Developing incentives and economic mechanisms for in situ biodiversity conservation in agricultural landscapes. Agriculture, Ecosystems and Environment 121(3):256-268. http://dx.doi.org/10.1016/j.agee.2006.12.025

Peeters, A., N. Dendoncker, and S. Jacobs. 2013. Enhancing ecosystem services in Belgian agriculture through agroecology: a vision for a farming with a future. Pages 285-304 in S. Jacobs, N. Dendoncker, and H. Keune, editors. Ecosystem services: global issues, local practices, Elsevier, New York, New York. http://dx. doi.org/10.1016/B978-0-12-419964-4.00022-6

Pirard, R., R. Billé, and T. Sembrés. 2010. Upscaling payments for environmental services (PES ): critical issues. Tropical Conservation Science 3:249-261. http://dx.doi.org/10.1177/194008291000300302

Ponisio, L., L. K. M'Gonigle, K. C. Mace, J. Palomino, P. de Valpine, and C. Kremen. 2014. Diversification practices reduce organic to conventional yield gap. Proceedings of the Royal Society B 282:20141396. http://dx.doi.org/10.1098/rspb.2014.1396

Porter, J., R. Costanza, H. Sandhu, L. Sigsgaard, and S. Wratten. 2009. The value of producing food, energy, and ecosystem services within an agroecosystem. AMBIO: A Journal of the Human Environment 38(4):186-193. http://dx.doi.org/https://doi. org/10.1579/0044-7447-38.4.186

Power, A. G. 2010. Ecosystem services and agriculture: tradeoffs and synergies. Philosophical Transactions of the Royal Society of London B: Biological Sciences 365(1554):2959-2971. http://dx. doi.org/10.1098/rstb.2010.0143

Prager, K., M. Reed, and A. Scott. 2012. Encouraging collaboration for the provision of ecosystem services at a landscape scale — rethinking agri-environmental payments. Land Use Policy 29(1):244-249. http://dx.doi.org/10.1016/j.

landusepol.2011.06.012

Rapidel, B., A. Ripoche, C. Allinne, A. Metay, O. Deheuvels, N. Lamanda, J.-M. Blazy, H. Valdés-Gómez, and C. Gary. 2015. Analysis of ecosystem services trade-offs to design agroecosystems with perennial crops. Agronomy for Sustainable Development 34(4):1373-1390. http://dx.doi.org/10.1007/s13593-015-0317$\mathrm{y}$
Raudsepp-Hearne, C., G.D. Peterson, and E.M. Bennett. 2010. Ecosystem service bundles for analyzing trade-offs in diverse landscapes. Proceedings of the National Academy of Sciences 107:5242-5247. http://dx.doi.org/10.1073/pnas.0907284107

Reed, M. S., A. Graves, N. Dandy, H. Posthumus, K. Hubacek, J. Morris, C. Prell, C. H. Quinn, and L. S. Stringer. 2009. Who's in and why? A typology of stakeholder analysis methods for natural resource management, Journal of Environmental Management 90(5):1933-1949. $\underline{\text { http://dx.doi.org/https://doi. }}$ org/10.1016/j.jenvman.2009.01.001

Robertson, M., and R. Prior-Murray. 2008. The challenge of engaging with farmers about the impacts of, and their adaptation to, climate change. The Regional Institute, Australia. [online] URL: http://www.regional.org.au/au/asa/2012/climatechange/7962 robertsonmj.htm

Sandhu, H. S., S. D. Wratten, and R. Cullen. 2010. Organic agriculture and ecosystem services. Environmental Science and Policy 13(1):1-7. http://dx.doi.org/10.1016/j.envsci.2009.11.002

Sen, A. 1995. Rationality and social choice. American Economic Review 85(1):1-24.

Servigne, P., and R. Stevens. 2015. Comment tout peut s'effondrer. Petit manuel de collapsologie à l'usage des générations présentes. Seuil, Paris, France.

Seufert, V., N. Ramankutty, and J. A. Foley. 2012. Comparing the yields of organic and conventional agriculture. Nature 485:229232. http://dx.doi.org/10.1038/nature11069

Spangenberg, J. H., C. von Haaren, and J. Settele. 2014. The ecosystem service cascade: further developing the metaphor. Integrating societal processes to accommodate social processes and planning, and the case of bioenergy. Ecological Economics 104:22-32. http://dx.doi.org/10.1016/j.ecolecon.2014.04.025

The Economics of Ecosystems and Biodiversity (TEEB). 2010. Mainstreaming the economics of nature: a synthesis of the approach, conclusions and recommendations of TEEB. TEEB, Geneva, Switzerland.

The Economics of Ecosystems and Biodiversity (TEEB). 2015. TEEB for agriculture and food. Interim Report, United Nations Environment Programme, Geneva, Switzerland.

Tilman, D., and M. Clark. 2014. Global diets link environmental sustainability and human health. Nature 515(7528):518-522. http://dx.doi.org/10.1038/nature13959

Tscharntke, T., A. M. Klein, A. Kruess, I. Steffan-Dewenter, and C. Thies. 2005. Landscape perspectives on agricultural intensification and biodiversity-ecosystem service management. Ecological Letters 8:857-874. http://dx.doi.org/10.1111/ j.1461-0248.2005.00782.x

Vatn, A. 2005. Rationality, institutions and environmental policy. Ecological Economics 55(2):203-217. http://dx.doi.org/10.1016/j. ecolecon.2004.12.001

Waylen, K. A., J. Martin-Ortega, K. L. Blackstock, I. Brown, B. E. Avendaño Uribe, S. Basurto Hernández, M. B. Bertoni, M. L. Bustos, A. X. Cruz Bayer, R. I. Escalante Semerena, M. A. Farah Quijano, F. Ferrelli, G. L. Fidalgo, I. Hernández López, M. A Huamantinco Cisneros, S. London, D. L. Maya Vélez, P. N. 
Ocampo-Díaz, C. E. Ortiz Guerrero, J. C. Pascale, G. M. E. Perillo, M. C. Piccolo, L. N. Pinzón Martínez, M. L. Rojas, F. Scordo, V. Vitale, and M. Zilio. 2015. Can scenario-planning support community-based natural resource management? Experiences from three countries in Latin America. Ecology and Society 20(4):28. http://dx.doi.org/10.5751/ES-07926-200428

Weisenburger, D. D. 1993. Human health effects of agrichemical use. Human Pathology 24(6), 571-576 http://dx.doi.org/10.1016/0046-8177 (93) $90234-8$

Wezel, A., S. Bellon, T. Doré, C. Francis, D. Vallod, and C. David. 2009. Agroecology as a science, a movement and a practice. A review. Agronomy for Sustainable Development 29(4):503-515. http://dx.doi.org/10.1007/978-94-007-0394-0_3

Zhang, W., T. H. Ricketts, C. Kremen, K. Carney, and S. M. Swinton. 2007. Ecosystem services and dis-services to agriculture. Ecological Economics 64:253-260. http://dx.doi.org/10.1016/j. ecolecon.2007.02.024 